\title{
PENGARUH KUALITAS PRODUK DAN HARGA TERHADAP KEPUTUSAN PEMBELIAN PADA TOKO PAKAIAN DISTRO ARJ88 STORE KOTA MATARAM
}

\author{
Kartika Oktafiani, Hilmiati Fauzi, Rusminah HS \\ Fakultas Ekonomi dan Bisnis \\ Universitas Mataram \\ E-mail : oktavianikartika036@gmail.com \\ DOI: https://doi.org/10.29303/ju.v1i1.36
}

\begin{abstract}
ABSTRAK
Penelitian ini bertujuan untuk mengetahui pengaruh dari variabel kualitas produk dan harga terhadap keputusan pembelian pada toko pakaian Distro Arj88 Store yang berada di Kota Mataram. Jenis penelitian yang digunakan dalam penelitian ini adalah asosiatif dengan pendekatan kuantitatif. Populasi pada penelitian ini adalah seluruh pembeli dan yang pernah datang berbelanja pada toko pakaian Distro Arj88 Store. Teknik pengambilan sampel menggunakan purposive sampling dengan jumlah sampel sebanyak 90 orang. Alat pengumpulan data menggunakan kuesioner yang telah di uji validitas dan reliabilitasnya. Uji analisis yang digunakan untuk menjawab hipotesis adalah analisis regresi linear berganda. Hasil dari penelitian ini menunjukan bahwa variabel Kualitas Produk berpengaruh signifikan terhadap keputusan pembelian dengan Nilai t hitung 6,287 > t tabel 1,988 dan nilai signifikansi $0,000>0,05$. Sedangkan variabel harga berpengaruh signifikan terhadap keputusan pembelian dengan dengan nilai $\mathrm{t}$ hitung 5,061 < t tabel 1,988 dan nilai signifikan $0,497<0,05$.
\end{abstract}

\section{Kata Kunci: Kualitas Produk, Harga, Keputusan Pembelian}

\begin{abstract}
This study aims to find out the influence of variable product quality and price on purchasing decisions at distro Arj88 Store clothing stores located in Mataram City. The type of research used in this research is associative with quantitative approach. The population in this research is all buyers and who have come shopping at the Distro clothing store Arj88 Store.Sampling techniques using purposive sampling with a total of 90 samples. Data collection tool using questionnaires that have been tested for validity and reliability. The analysis test used to answer hypotheses is multiple linear regression analysis. The results of this study showed that Product Quality Variables had a significant effect on purchasing decisions with a calculated $t$ value of 6,287 > t table of 1,988 and a significance value of $0.000>0.05$. While the price variable has a significant effect on the purchase decision with a calculated $t$ value of 5,061 $<$ t table 1,988 and a significant value of 0.497 $<0.05$.
\end{abstract}

Keywords: Product Quality, Price, Purchase Decision 


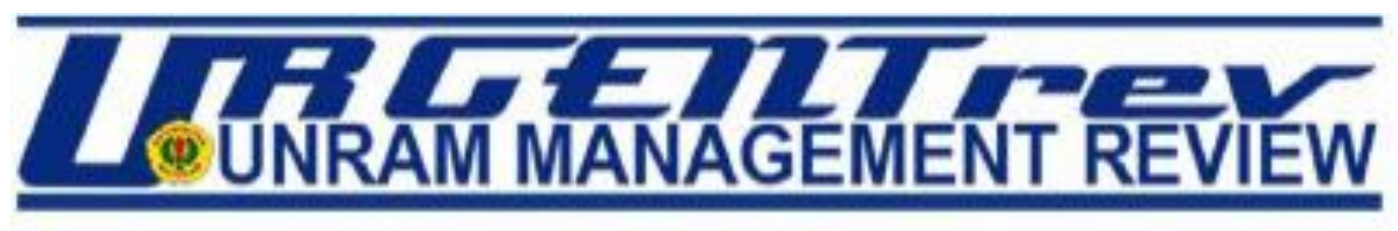

\section{PENDAHULUAN}

Perkembangan bisnis di era globalisasi dan teknologi yang semakin maju membuat konsumen dihadapkan pada kondisi yang berubah dari sebelumnya. Setiap pelaku usaha di tiap kategori bisnis dituntut untuk memiliki kepekaan terhadap setiap perubahan yang terjadi dan menempatkan orientasi kepada kepuasan pelanggan sebagai tujuan utama (Kotler, 2005). Tidak terkecuali usaha dalam pakaian yang dimulai dari skala kecil seperti membuka lapak di pasar, dan hanya menjual melalui online, bisnis pakaian berskala menengah seperti distro dan butik, sampai dengan bisnis pakaian yang berskala besar seperti department store di mall-mall besar.

Semakin ketatnya persaingan bisnis yang ada, terutama persaingan yang berasal dari perusahaan sejenis, membuat perusahaan semakin dituntut agar bergerak lebih cepat dalam hal menarik konsumen. Sehingga perusahaan yang menerapkan konsep pemasaran perlu mencermati perilaku konsumen dan faktor-faktor yang mempengaruhi keputusan pembeliannya dalam usaha-usaha pemasaran sebuah produk yang dilakukan. Hal tersebut dikarenakan konsep salah satu cara untuk mencapai tujuan perusahaan adalah dengan mengetahui apa kebutuhan dan keinginan konsumen atau pasar sasaran serta memberikan kepuasan yang diharapkan secara lebih efektif dan efisien dibandingkan para pesaing (Kotler, 1997)

Kegiatan penjualan adalah kegiatan yang penting, karena dengan adanya kegiatan penjualan tersebut maka akan terbentuk laba yang dapat menjamin kelangsungan hidup perusahaan. Keberhasilan suatu perusahaan dalam mencapai tujuan itu sangat dipengaruhi oleh kemampuan perusahaan dalam memasarkan produknya.

Dalam Proses pengambilan keputusan pembelian diawali dengan adanya kebutuhan. Konsumen dalam mengambil keputusan untuk membeli suatu produk yang ditawarkan banyak dipengaruhi oleh persepsinya terhadap harga, produk, promosi, tempat yang telah diterapkan oleh perusahaan selama ini.

Keputusan pembelian merupakan keputusan seseorang yang mana dia memilih salah satu dari alternatif pilihan dan proses intergrasi yang menggabungkan sikap pengetahuan untuk mengevaluasi dua atau lebih perilaku alternatif dan memilih satu diantaranya. Menurut Kodu (2013) keputusan pembelian merupakan sikap seseorang untuk membeli atau menggunakan suatu produk baik berupa barang atau jasa yang telah diyakini akan memuaskan dirinya dan kesediaan menanggung resiko yang mungkin ditimbulkannya. Keputusan pembelian adalah tahap dimana pembeli telah menentukan pilihannya dan melakukan pembelian produk, serta mengkonsumsinya. Sedangkan Petricia \& Syahputra (2014) menyatakan keputusan pembelian merupakan pemilihan dari dua atau lebih alternatif pilihan keputusan pembelian, artinya bahwa seseorang dapat membuat keputusan, haruslah tersedia beberapa alternatif pilihan. Memutuskan berarti memilih salah satu dua dari alternatif. Meskipun pemasaran sering merujuk tentang pemilihan antara objek (barang, merek. toko, tempat belanja), konsumen sebenarnya memilih antara alternatif perilaku yang berkenaan dengan objek tersebut.

Menurut Kotler dan Keller (2012:170) keputusan pembelian adalah tahap evaluasi, konsumen dari preferensi di antara merek di set pilihan dan mungkin juga dari niat untuk membeli merek yang paling disukai. setelah tahap keputusan pembelian ini akan muncul pengalaman pembelian pada konsumen, jika konsumen merasa puas akan produk yang dibeli maka kemungkinan besar dimasa yang akan datang konsumen akan membeli dengan produk yang sama dan begitupun sebaliknya jika konsumen merasa tidak puas akan produk yang dibeli maka 


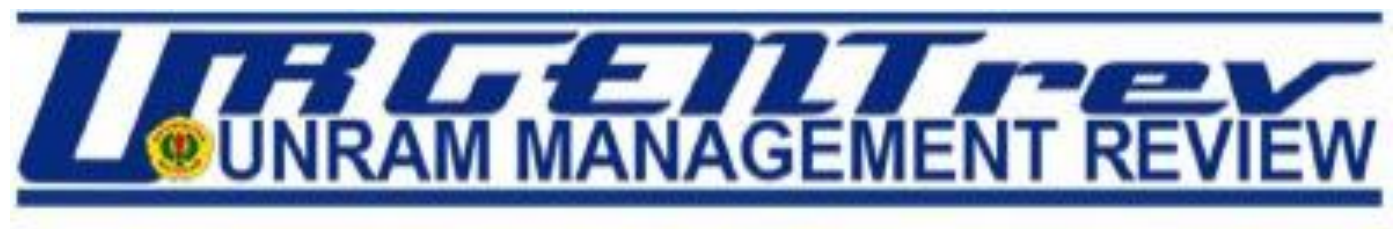

kemungkinan besar konsumen tidak akan membeli produk yang sama atau berganti ke merek lain.

Keputusan pembelian merupakan suatu hal yang sangat penting untuk diperhatikan karena keputusan pembelian merupakan hal yang digunakan oleh perusahaan untuk menciptakan strategi pemasaran yang akan dilakukan. Salah satu hal yang perlu diperhatikan oleh perusahaan dalam melakukan pemasaran produk yang akan dijual adalah dengan memahami kebutuhan konsumen, mengetahui keinginan konsumen dan selera dari pada konsumen. Pemahaman yang mendalam mengenai konsumen akan memungkinkan pemasar dapat mempengaruhi proses keputusan konsumen, sehingga mau membeli apa yang ditawarkan oleh pemasar. (Sumarwan, 2003 )

Menurut Kotler \& Keller (2009:160), yang dimaksud dengan keputusan pembelian adalah konsumen membentuk niat untuk membeli merek yang paling disukai dan menurut Kotler (2002:178), Keputusan pembelian adalah tindakan dari konsumen untuk mau membeli atau tidak terhadap produk. Dari berbagai faktor yang mempengaruhi konsumen dalam melakukan pembelian suatu produk atau jasa, biasanya konsumen selalu mempertimbangkan kualitas, harga dan produk yang sudah dikenal oleh masyarakat sebelum konsumen memutuskan untuk membeli, biasanyaa konsumen melalui beberapa tahap terlebih dahulu yaitu, (1) pengenalan masalah, (2) pencarian informasi, (3) evaluasi alteernatif, (4) keputusan membeli atau tidak, (5) perilaku pasca pembelian.

Setiap konsumen yang akan melakukan pembelian pada suatu produk pasti akan mempertimbangkan beberapa hal yang mendukung keputusan pembelian tersebut. Seperti kualitas produk, dalam pandangan Ingga (2017:163) kualitas produk adalah sesuatu yang memenuhi atau melebihi harapan pelanggan. Sedangkan menurut Cannon (2008:286) kualitas berarti kemampuan produk untuk memuaskan kebutuhan atau keinginan pelanggan, sedangkan produk berarti kepuasan akan kebutuhan yang ditawarkan oleh suatu perusahaan. Dari definisi di atas dapat disimpulkan bahwa kualitas produk merupakan sesuatu yang memenuhi atau melebihi harapan pelanggan untuk memuaskan kebutuhan atau keinginan pelanggan yang ditawarkan oleh suatu perusahaan.

Kualitas produk yang ditawarkan oleh Arj88 Store lebih didefinisikan sebagai keandalan, estetika yang tinggi atau konfirmasi dimana produk yang ditawarkan dengan bahan kain yang halus tidak kalah dengan distro yang lainnya. Dengan demikian, Arj88 memiliki keunggulan dibandingkan dengan distro lain yang kebanyakan menggunakan bahannya sama dan kualitas sama.

Kualitas produk pada dasarnya dapat memberikan pengaruh positif terhadap keputusan pembelian seorang konsumen. Kualitas produk merupakan pemahaman bahwa produk yang ditawarkan oleh penjual mempunyai nilai jual lebih yang tidak dimiliki oleh produk pesaing. Oleh karena itu perusahaan berusaha memfokuskan pada kualitas produk dan membandingkannya dengan produk yang ditawarkan oleh perusahaan pesaing. Atribut produk adalah karakteristik produk, dapat berwujud, karakteristik subyektif. Atribut produk bagi usaha pemasaran merupakansalah satu cara untuk dapat memenangkan persaingan dipasar, karena atribut produk tersebut merupakan alat untuk membedakan produk perusahaan dengan produk pesaing (Purnama, 2018). Akan tetapi, suatu produk dengan penampilan terbaik atau bahkan dengan tampilan lebih baik bukanlah merupakan produk dengan kualitas tertinggi jika tampilannya bukanlah yang dibutuhkan dan diinginkan oleh pasar.

Menurut Tjiptono, (2008:250) kualitas merupakan suatu kondisi dinamis yang berpengaruh dengan produk, jasa, 


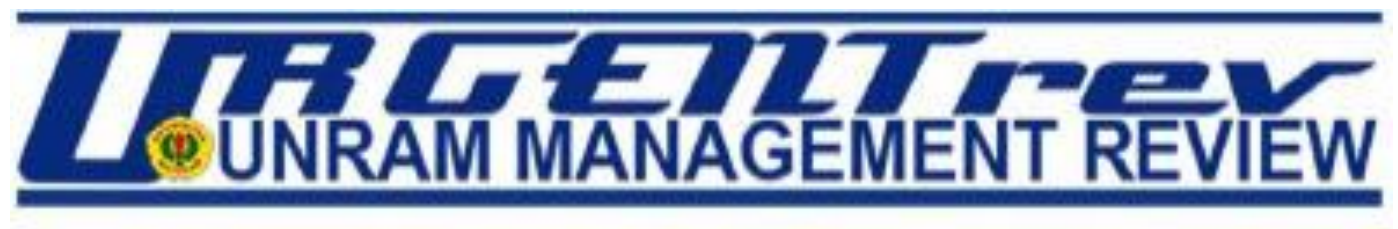

manusia, proses dan lingkungan yang memenuhi atau melebihi harapan. Dengan demikian, kualitas pelayanan dapat diartikan sebagai upaya pemenuhan kebutuhan dan keinginan konsumen serta ketepatan penyampaiannya dalam mengimbangi harapan konsumen.

Oleh karena itu untuk menarik konsumen melakukan pembelian maka perusahaan harus bisa menerapkan suatu strategi pemasaran yang tepat sesuai dengan kondisi pasar yang di hadapi. Maka salah satu sistem pemasaran yang digunakan perusahaan dalam memasarkan produknya adalah dengan harga. Harga digunakan sebagai alat dalam membantu penjualan, dilain pihak juga digunakan untuk membangun citra jangka panjang suatu produk. Harga harus mampu membujuk konsumen agar berperilaku sedemikian rupa sehingga mampu memberikan keuntungan bagi perusahaan. Dalam sejarah, harga merupakan faktor penting yang mempengaruhi pilihan dari seseorang untuk membeli. (Siti Istiqomah, 2019)

Selain harga, kualitas produk juga telah menjadi bagian dari strategi bisnis untuk meningkatkan keunggulan bersaing. Perusahaan yang menjadikan kualitas sebagai alat strategi akan mempunyai keunggulan bersaing terhadap pesaingpesaingnya dalam menguasai pasar, karena tidak semua perusahaan mampu mencapai superioritas. Salah satu usaha yang dilakukan oleh Toko Pakaian Distro Arj88 Store dalam mempertahankan konsumennya adalah dengan meningkatkan kualitas produknya baik dari segi harga maupun kualitas produknya sehingga konsumen akan tetap melakukan pembelian terhadap produk tersebut.

Harga adalah jumlah uang yang harus dibayar pelanggan untuk memperoleh produk tersebut (Aristo 2016). Harga adalah jumlah uang ditambah beberapa produk apabila memungkinkan yang dibutuhkan untuk mendapatkan sejumlah kombinasi dari produk dan pelayanannya (Martini 2015).
Harga yang ditawarkan oleh Distro Arj88 Store dapat dikategorikan sebagai harga yang cukup terjangkau apabila dibandingkan dengan harga yang ditawarkan oleh para pesaingnya seperti Furios Store, Muma store, Wild Time, Simple store, Anything, Glory Store, Basic dll. Harga yang cukup terjangkau menjadi salah satu daya tarik bagi konsumen untuk memilih Arj88 Store dibandingkan dengan distro lainnya. (Akrim Ashal Lubis. 2015 )

Melalui koleksi pakaian distro andalannya. Serta mampu memberikan/ menyediakan pelayanan yang memuaskan untuk seluruh pelanggan setianya. Dengan memiliki kualitas produk yang tidak kalah dengan distro lainnya Arj88 store juga memiliki harga yang bisa dijangkau oleh berbagai kalangan terutama kalangan anak muda.

Arj88 Store berdiri sejak tahun 2016. Dengan berlokasi di komplek pertokoan Alam Dewata No. 25 jalan Dewata Sidekarya Denpasar Selatan. Arj88 store mampu bersaing dengan bisnis-bisnis lain pada areanya. Arj88 store memliki tiga cabang di lombok dengan berlokasi di Sedangkan lokasi penelitian ini berlokasi di jl. Sriwijaya No. 84, Cilinaya, Kec. Cakranegara, Kota Mataram.

Melalui koleksi pakaian distro andalannya. Serta mampu memberikan / menyediakan pelayanan yang memuaskan untuk seluruh pelanggan setianya. Dengan memiliki kualitas produk yang tidak kalah dengan distro lainnya Arj88 store juga memiliki harga yang bisa dijangkau oleh berbagai kalangan terutama kalangan anak muda.

Kota Mataram merupakan ibu kota Provinsi Nusa Tenggara Barat, Indonesia. Adat Sasak dan Adat Bali cukup mewarnai masyarakat di kota ini. Jumlah penduduk kota Mataram tahun 2019 berjumlah 495.681 jiwa.

Mataram selain dikenal sebagai ibu kota Propinsi Nusa Tenggara Barat juga dikenal sebagai ibu kota Pemda Kota Mataram. Kota Mataram yang letaknya sangat strategis dan menjadi pusat berbagai 


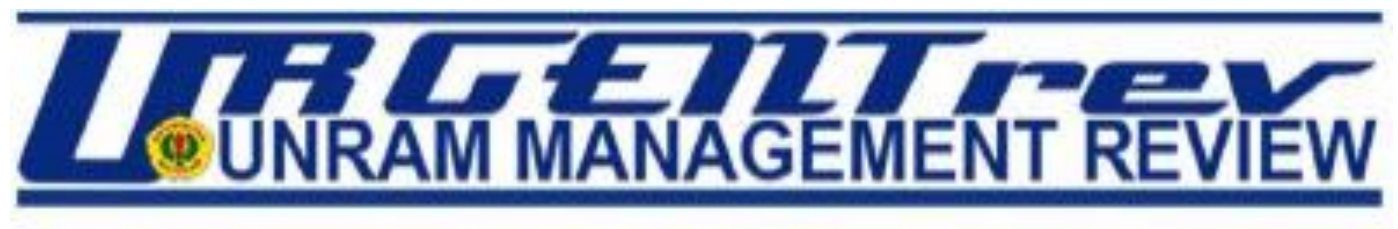

aktifitas seperti pusat pemerintahan, pendidikan, perdagangan, industri dan jasa, saat ini sedang dikembangkan untuk menjadi kota pariwisata. Keberadaan berbagai fasilitas penunjang seperti fasilitas perhubungan seperti Bandara Internasional Selaparang sebagai pintu masuk Lombok melalui udara, pusat perbelanjaan, dan jalur transportasi yang menghubungkan antar kabupaten dan propinsi inilah yang menjadi pertimbangan dalam pengembangan Kota Mataram menjadi kota pariwisata.

Berdasarkan uraian diatas, maka penulis memutuskan untuk melakukan penelitian dengan judul "Pengaruh Kualitas Produk dan Harga Terhadap Keputusan Pembelian Pada Toko pakaian Distro Arj88 Store Kota Mataram "

\section{Rumusan Masalah}

Beradasarkan latar belakang diatas bahwa dapat disimpulkan bahwa keputusan pembelian pada toko pakaian distro dapat dipengaruhi banyak faktor-faktor pendorong. Akan tetapi dari latar belakang diatas belum bisa ditentukan apakah kualitas produk dan harga dapat mempengaruhi keputusan pembelian toko pakaian Distro Arj88 Store. Oleh karena itu, masalah yang di angkat dalam penelitian ini :

1. Apakah kualitas produk berpengaruh signifkan terhadap keputusan pembelian pada toko pakaian Distro Arj88 store Kota Mataram ?

2. Apakah harga berpengaruh signifikan terhadap keputusan pembelian pada toko pakaian Distro Arj88 store Kota Mataram ?

\section{KAJIAN PUSTAKA \\ Keputusan Pembelian}

Keputusan pembelian merupakan kegiatan individu yang secara langsung terlibat dalam pengambilan keputusan untuk melakukan pembelian terhadap produk yang ditawarkan oleh penjual. Kotler dan Keller (2012:170) mendefinisikan keputusan pembelian adalah tahap evaluasi, konsumen dari preferensi di antara merek di set pilihan dan mungkin juga dari niat untuk membeli merek yang paling disukai. Keputusan pembelian adalah salah satu tahapan dalam proses keputusan pembelian sebelum perilaku pasca pembelian. Dalam memasuki tahapan keputusan pembelian , sebelumnya konsumen sudah dihadapkan pada bebrapa pilihan alternatif sehingga pada tahap ini konsumen akan melakukan aksi untuk membeli suatu produk berdasarkan pilihan yang ditentukan.

Keputusan pembelian merupakan seleksi terhadap dua pilihan alternatif atau lebih. Bagi konsumen, proses keputusan merupakan kegiatan penting karena didalam proses keputusan pembelian merupakan kegiatan penting karena didalam proses tersebut memuat berbagai langkah yang terjadi secara berurutan sebelum konsumen mengambil keputusan. Bila konsumen memutuskan untuk membeli, konsumen akan menjumpai serangkaian keputusan yang harus di ambil menyangkut jenis produk, merek, penjual, kualitas, waktu pembelian, dan cara pembayarannya. Maka setiap perusahaan dapat mengusahakan untuk menyederhanakan pengambilan keputusan yang akan dilakukan oleh para konsumen (Dharmmesta dan Handoko :110)

\section{Indikator Keputusan Pembelian}

Menurut Kotler dalam (Sanjaya 2015:123) adapun indikator-indikator keputusan pembelian adalah sebagai berikut :

1. Pembelian produk, adalah proses pembelian yang dilakukan konsumen dalam membeli barang atau jasa yang diinginkan.

2. Pembelian merek, adalah proses pembelian yang dilakukan konsumen yang hanya mempertimbangkan merek dari produknya saja.

3. Pemilihan saluran pembelian, adalah setiap barang yang ingin dibeli konsumen harus di pilih terlebih dahulu dalam saluran pembelian. 


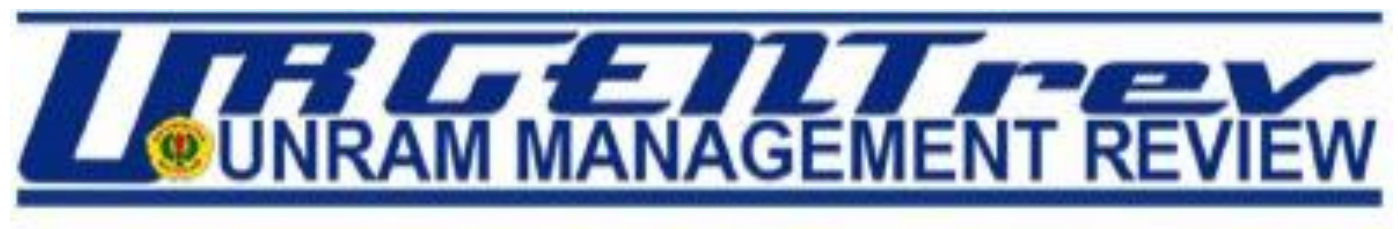

4. Penentuan waktu pembelian, adalah setiap konsumen ingin membeli produk atau barang yang diinginkan konsumen harus terlebih dahulu menentukan kapan waktu pembelian yang sudah dijadwalkan konsumen.

5. Jumlah, adalah berpa banyak produk yang diingikan atau dibeli konsumen.

\section{Kualitas Produk}

Menurut Kotler (2009:180), Kualitas adalah totalitas fitur dan karateristik produk atau jasa yang bergantung pada kemampuannya untuk memuaskan kebutuhan yang dinyatakan atau tersirat. Menurut Kotler dan Amstrong (2008:250), kualitas adalah karateristik produk atau jasa yang bergantung pada kemampuannya untuk memuaskan kebutuhan pelanggan yang dinyatakan atau diimplikasikan. Kualitas merupakan hal yang perlu mendapat perhatian utama dari perusahaan atau produsen, mengingat kualitas dari produk berkaitan erat dengan masalah keputusan suatu konsumen yang merupakan tujuan dari kegiatan pemasaran yang dilakukan perusahaan. Menurut Kotler dan Amstrong (2008:251), produk adalah segala sesuatu yang di tawarkan ke pasar untuk mendapatkan perhatian, dibeli, dipergunakan dan yang dapat memuaskan keinginan atau kebutuhan konsumen. Menurut Etta Mamang dan Sopiah (2012), bahwa kualitas merupakan suatu kondisi dinamis yang berhubungan dengan produk, jasa, manusia, proses, dan lingkungan yang memenuhi atau melebihi harapan.Dari beberapa pendapat di atas dapat disimpulkan bahwa kualitas produk merupakan upaya atau kemampuan yang dilakukan perusahaan dalam memberikan kepuasan bagi konsumen, karena kepuasan konsumen tidak hanya mengacup ada betukfisik produk, melainkan satu paket kepuasan yang dapat dari pembelian produk.

\section{Indikator Kualitas Produk}

Etta Mamang dan Sopiah (2012), menyatakan bahwa kualita sproduk dapat diukur dengan menggunakan beberapa indikator diantaranya sebagai berikut :

1. Kinerja. Merupakan elemen kualitas produk yang berkaitan langsung dengan bagaimana suatu produk dapat menjalankan fungsinya untuk memenuhi kebutuhan konsumen.

2. Reliabilitas. Merupakan daya tahan produk selama dikonsumsi.

3. Fitur. Merupakan fungsi-fungsi sekunder yang ditambahkan pada suatu produk, misal fitur kendali jauh.

4. Keawetan (durability). Dimensi kualitas produk yang menunjukkan suatu pengukuran terhadap siklus produk, baik secara teknis maupun waktu.Produk dikatakan awet jika dapat bertahan dalam pemakaian yang berulang-ulang.

5. Konsistensi. Yang menunjukkan seberapa jauh suatu produk bisa memenuhi standar atau spesifikasi tertentu. Produk yang mempunyai konsistensi tinggiberarti sesuai dengan standart yang ditentukan.

6. Desain. Merupakan aspek emosional untuk mempengaruhi kepuasan konsumen sehingga desain kemasan ataupun bentuk produk akan turut memengaruhi persepsi kualitas produk tersebut.

\section{Harga}

Menurut (Kotler \& Amstrong, 2011:178), menyatakan harga dalam arti yang sempit adalah jumlah yang ditagihkan atas suatu produk atau jasa. Lebih luas lagi, harga adalah jumlah semua nilai yang diberikan oleh pelanggan untuk mendapatkan keuntungan dari memiliki atau menggunakan suatu produk atau jasa. Menurut (Farida, Tarmizi, \& November, 2016), harga (price) adalah Elemen penting yang menempel pada sebuah produk. Harga menjadi kunci utama bagi konsumen untuk membeli barang, khususnya konsumen untuk membeli barang, khususnya konsumen kelas menengah ke bawah dalam pemasaran, penetuan harga 


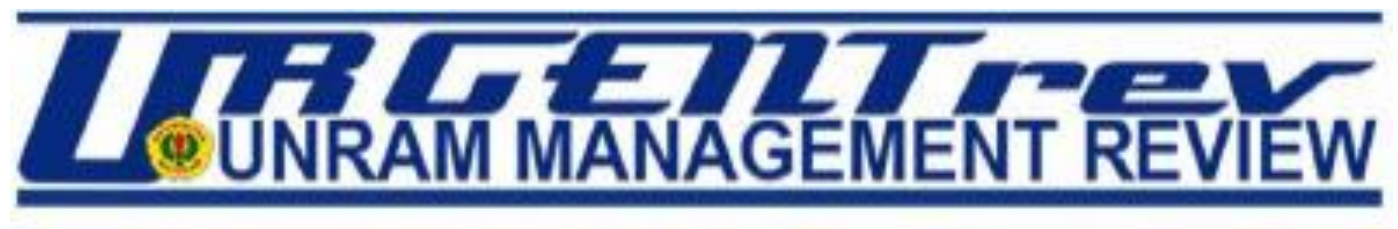

bisa menjadi kekuatan untuk bersaing di dalam pasar.

Sedangkan menurut (Alma, 2013), harga adalah nilai dari suatu barang yang dapat dinyatakan dengan uang. Sehingga definisi harga adalah alat pengukur dasar sebuah sistem ekonomi karena harga mempengaruhi alokasi faktor-faktor produksi. dan harga juga dapat didefinisikan sebagai jumlah uang yang dibutuhkan untuk memperoleh beberapa kombinasi sebuah produk dan pelayanan yang menyertainya. Menurut (Kotler \& Amstrong, 2012:190), didalam variabel harga ada beberapa unsur kegiatan utama harga yang meliputi daftar harga, diskon, potongan harga, dan periode pembayaran. Menurut (Riyono \& Budiharja, 2016) ada empat indikator yang mencirikan harga yaitu: Keterjangkauan harga, kesesuaian harga dengan kualitas produk, daya saing harga, kesesuaian harga dengan manfaat.

\section{Indikator Harga}

Indikator Harga Menurut Kotler dan Amstrong (2008:187), ada empat indikator yang mencirikan harga yaitu, keterjangkauan harga, kesesuaian harga dengan kualitas produk, daya saing harga, kesesuaian harga dengan manfaat.

a. Keterjangkauan harga, yaitu aspek penetapan harga yang dilakukan oleh produsen/penjual yang sesuai dengan kemampuan beli konsumen.

b. Daya saing harga, yaitu penawaran harga yang diberikan oleh produsen/penjual berbeda dan bersaing dengan yang diberikan oleh produsen lain, pada satu jenis produk yang sama.

c. Kesesuaian harga dengan kualitas produk, yaitu aspek penetapan harga yang dilakukan oleh produsen/penjual yang sesuai dengan kualitas produk yang dapat diperoleh konsumen.

d. Kesesuaian harga dengan manfaat produk, yaitu aspek penetapan harga yang dilakukan oleh produsen/penjual yang sesuai dengan manfaat yang dapat diperoleh konsumen dari produk yang dibeli.

\section{METODE PENELITIAN}

Penelitian ini merupakan penelitian asosiatif dengan pendekatan kuantitatif, berlokasi di kota Mataram. Metode pengumpulan data yang digunakan dalam penelitian ini menggunakan metode sampel survey. Penentuan pengambilan jumlah sampel dilakukan melalui teknik non probability sampling dengan metode purposive sampling, teknik pengumpulan data menggunakan angket dan wawancara. Alat pengumpulan data berupa kuisioner yang disebar secara online. Skala pengukuran variabel menggunakan skala interval dari 1-5. 


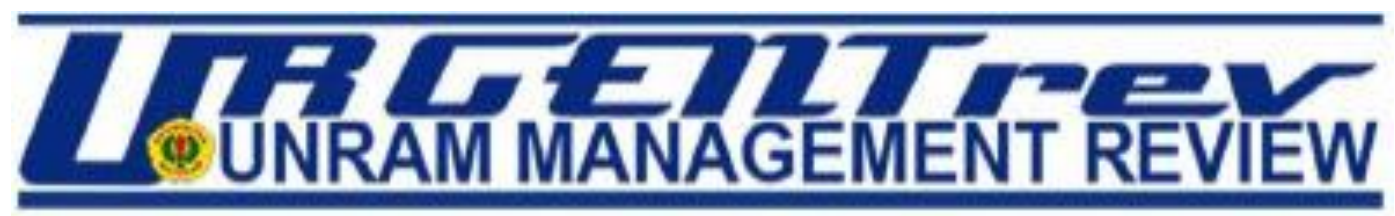

Vol. 1 No. 1 Oktober 2021

๑.ISSN. 2809-4263

urgentrev.unram.ac.id

Tabel 1 Uji Reliabilitas

\begin{tabular}{|c|c|c|c|c|}
\hline Variabel & $\begin{array}{c}\text { Cronbac } \\
\boldsymbol{h} \text { 's } \\
\text { Alpha }\end{array}$ & $\mathbf{N}$ & $\begin{array}{c}\text { Nilai } \\
\text { Batas }\end{array}$ & Ket. \\
\hline $\begin{array}{c}\text { Kualitas } \\
\text { Produk }\end{array}$ & 0,856 & 6 & 0,7 & $\begin{array}{c}\text { Reliabe } \\
\boldsymbol{l}\end{array}$ \\
\hline Harga & 0,909 & 7 & 0,7 & $\begin{array}{c}\text { Reliabe } \\
\boldsymbol{l}\end{array}$ \\
\hline $\begin{array}{c}\text { Keputusan } \\
\text { Pembelian }\end{array}$ & 0,927 & 7 & 0,7 & $\begin{array}{c}\text { Reliabe } \\
\boldsymbol{l}\end{array}$ \\
\hline
\end{tabular}

Keterangan :

I : Besar Interval kelas

$\mathrm{R}$ : Range (Kelas)

$\mathrm{K}$ : Jumlah Interval Kelas

Tabel 2 Memperlihatkan Hasil Uji

\begin{tabular}{|c|c|c|c|c|}
\hline & Pertanyaan & R hitung & R tabel & Ket. \\
\hline \multicolumn{5}{|c|}{ KUALITAS PRODUK (X1) } \\
\hline 1 & X1.1 & 0,762 & 0,207 & Valid \\
\hline 2 & X1.2 & 0,793 & 0,207 & Valid \\
\hline 3 & X1.3 & 0,707 & 0,207 & Valid \\
\hline 4 & X1.4 & 0,734 & 0,207 & Valid \\
\hline 5 & X1.5 & 0,802 & 0,207 & Valid \\
\hline 6 & X1.6 & 0,797 & 0,207 & Valid \\
\hline \multicolumn{5}{|c|}{ HARGA (X2) } \\
\hline 1 & X2.1 & 0,762 & 0,207 & Valid \\
\hline 2 & X2.2 & 0,705 & 0,207 & Valid \\
\hline 3 & X2.3 & 0,775 & 0,207 & Valid \\
\hline 4 & X2.4 & 0,861 & 0,207 & Valid \\
\hline 5 & X2.5 & 0,843 & 0,207 & Valid \\
\hline 6 & X2.6 & 0,863 & 0,207 & Valid \\
\hline 7 & X2.7 & 0,833 & 0,207 & Valid \\
\hline \multicolumn{5}{|c|}{ KEPUTUSAN PEMBELIAN(Y) } \\
\hline 1 & Y.1 & 0,844 & 0,207 & Valid \\
\hline 2 & Y.2 & 0,825 & 0,207 & Valid \\
\hline 3 & Y.3 & 0,836 & 0,207 & Valid \\
\hline 4 & Y.4 & 0,833 & 0,207 & Valid \\
\hline 5 & Y.5 & 0,843 & 0,207 & Valid \\
\hline 6 & Y.6 & 0,858 & 0,207 & Valid \\
\hline 7 & Y.7 & 0,805 & 0,207 & Valid \\
\hline
\end{tabular}

\section{HASIL DAN PEMBAHASAN}

Uji validitas digunakan untuk mengukur sah atau valid tidaknya suatu kuesioner. Suatu kuesioner dikatakan valid jika pertanyaan pada kuisioner mampu untuk mengungkapkan sesuatu yang akan diukur oleh kuesioner tersebut. Cara mengukur validitas dengan melakukan korelasi antar skor butir pertanyaan dengan total skor variabel. Jika $r$ hitung $>r$ tabel dan nilai positif, maka maka pertanyaan atau indikator dikatakan valid (Ghozali, 2006;45).

Berdasarkan tabel tersebut, nilai $r$ hitung masing-masing pertanyaan lebih besar dibandingkan $r$ tabel yang sebesar 0,207 . Dengan demikian, setiap item pernyataan ini dapat dianggap valid dan dapat digunakan dalam penelitian.

Dalam penelitian ini untuk menguji reliabilitas instrumen dalam penelitian, menggunakan koefisien reliabilitas Alpha Cronbach. Instrumen penelitian dikatakan reliabel jika memiliki nilai Alpha Cronbach $>0,70$ jika nilainya lebih kecil dari 0,70 maka kuesioner penelitian ini tidak reliabel (Sanusi, 2011).

Reabilitas masing-masing item pernyataan untuk variabel Kualitas Produk, Harga, Keputusan Pembelian. Berdasarkan tabel diatas diketahui bahwa nilai Cronbach's Alpha pada masing-masing variabel menunjukkan nilai yang lebih besar dari 0,7. Dengan demikian keseluruhan pertanyaan didalam kuisioner pada penelitian ini adalah reliable dan dapat digunakan dalam penelitian.

Analisis regresi linear berganda adalah analisis yang mengukur pengaruh variabel bebas terhadap variabel terikat. Pengukuran pengaruh ini melibatkan satu variabel bebas dan variabel terikat, yang dinamakan analisis regresi linier berganda (Malhotra, 2007). 


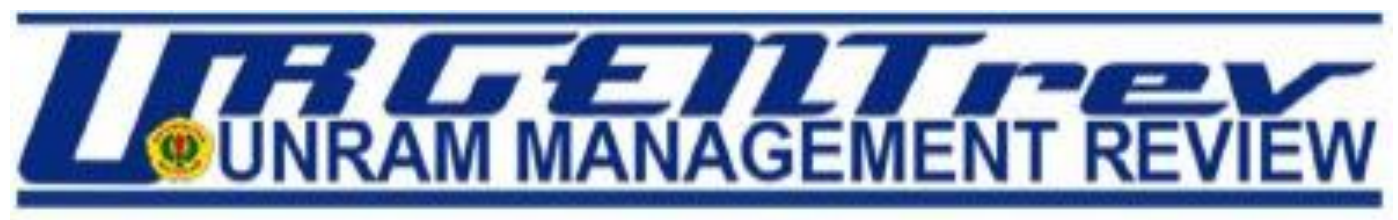

Vol. 1 No. 1 Oktober 2021

e.ISSN. 2809-4263

urgentrev.unram.ac.id

Tabel 3 Hasil Uji Regresi Linier Berganda

Tabel 4 Uji Parsial ( Uji - t)

Coefficients $^{\mathrm{a}}$

\begin{tabular}{|c|c|c|c|}
\hline \multirow[b]{2}{*}{ Model } & \multicolumn{2}{|c|}{$\begin{array}{l}\text { Unstandardize } \\
\text { d Coefficients }\end{array}$} & $\begin{array}{l}\text { Standardized } \\
\text { Coefficients }\end{array}$ \\
\hline & B & $\begin{array}{l}\text { Std. } \\
\text { Error }\end{array}$ & Beta \\
\hline $1 \quad$ (Constant) & -1.027 & 1.546 & \\
\hline Total_X1 & .687 & .109 & .520 \\
\hline Total_X2 & .438 & .086 & .419 \\
\hline
\end{tabular}

Berdasarkan hasil pengolahan regresi linear berganda yang ditunjukan dalam tabel 3 maka diperoleh persamaan regresi berganda sebagai berikut:

$$
\mathrm{Y}=-1.027+0.687 \mathrm{X} 1+0.438 \mathrm{X} 2+\mathrm{e}
$$

Untuk lebih jelasnya masingmasing koefisien dari persamaan regresi akan dijelaskan sebagai berikut:

1. Nilai $\alpha$ sama dengan -1.027 bernilai positif mengindentifikasikan bahwa jika tidak ada perubahan pada nilai nilai $\mathrm{X} 1$ dan $\mathrm{X} 2$ maka nilai $\mathrm{Y}$ akan sebesar -1.027

2. Nilai koefisien X1 ( $\beta 1)$ sama dengan 0.687 bernilai positif mengidentifikasikan bahwa jika nilai X1 meningkat satu satuan maka nilai $\mathrm{Y}$ akan meningkat sebesar 0.687 satuan dengan asumsi $\mathrm{X} 2$ bernilai konstan. 3. Nilai koefisien X2 ( $\beta 2)$ sama dengan 0.438 bernilai positif mengindentifikasikan bahwa jika nilai $\mathrm{X} 2$ meningkat satu satuan maka nilai Y akan meningkat sebesar 0.438 satuan dengan asumsi X1 bernilai konstan.

Berikutnya berdasarkan hasil uji parsial (uji t) yang telah diolah dalam penelitian ini, didapatkan hasil sebagai berikut.

\begin{tabular}{|r|c|c|c|c|c|}
\hline \multirow{2}{*}{ Model } & \multicolumn{2}{|c|}{$\begin{array}{c}\text { Unstandardized } \\
\text { Coefficients }\end{array}$} & $\begin{array}{c}\text { Stand } \\
\text { Coeff }\end{array}$ & \multirow{2}{*}{$\mathrm{t}$} & \multirow{2}{*}{ Sig. } \\
\cline { 2 - 4 } & B & Std. Error & Beta & & \\
\hline (Constant) & -1.027 & 1.546 & & -.664 & .508 \\
1 Total_X1 & .687 & .109 & .520 & 6.287 & .000 \\
Total_X2 & .438 & .086 & .419 & 5.061 & .000 \\
\hline \multicolumn{7}{|c|}{ a. Dependent Variable: Total_Y } \\
\hline
\end{tabular}

Berdasarkan hasil pengujian pada Tabel 4 maka pengaruh Kualitas Produk dan Harga Terhadap Keputusan Pembelian dapat dijelaskan sebagai berikut:

1. Pengujian Hipotesis Pertama

Berdasarkan Tabel 4 diatas, diperoleh hasil bahwa variabel Kualitas Produk memiliki nilai $\mathrm{t}$ hitung sebesar 6,287 dengan signifikansi sebesar 0,000 . Nilai $\mathrm{t}$ hitung lebih besar dibandingkan $\mathrm{t}$ tabel $(6,287>1,988)$ dan nilai signifikansi lebih kecil dari $0,05(0,000<0,05)$ menunjukkan bahwa, Kualitas Produk mempengaruhi keputusan pembelian secara statistik.

2. Pengujian Hipotesis Kedua

Berdasarkan Tabel diatas, diperoleh hasil bahwa variabel Harga memiliki nilai t hitung sebesar 5,061 signifikansi sebesar 0,000. Nilai t hitung lebih kecil dibandingkan $t$ tabel $(5,061<1,988)$ dan nilai signifikansi lebih besar dari 0,05 $(0,000>0,05)$ menunjukkan bahwa, Harga mempengaruhi keputusan pembelian secara statistik.

Selanjutnya berdasarkan hasil uji kelayakan model (uji f) yang telah diolah dalam penelitian ini, didapatkan hasil sebagai berikut. 


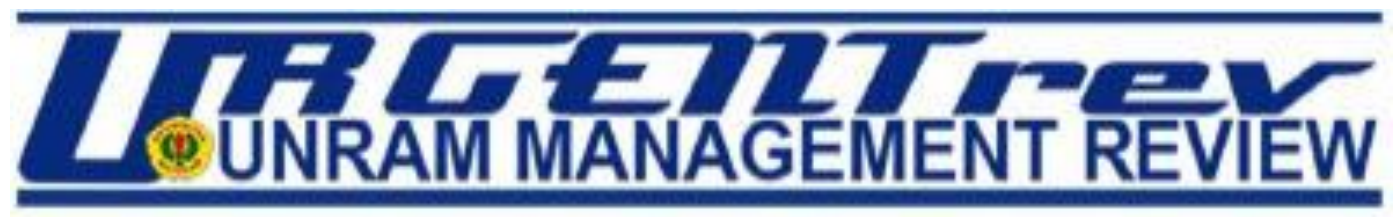

Vol. 1 No. 1 Oktober 2021

Tabel 5 Uji Kelayakan Model (Uji - F)

ANOVA $^{b}$

\begin{tabular}{|ll|r|r|r|c|c|}
\hline \multicolumn{1}{|c|}{ Model } & $\begin{array}{r}\text { Sum of } \\
\text { Squares }\end{array}$ & df & Mean Square & F & Sig. \\
\hline $1 \quad$ Regression & 1833.229 & 2 & 916.615 & 176.002 & $.000^{a}$ \\
Residual & 453.093 & 87 & 5.208 & & \\
Total & 2286.322 & 89 & & & \\
\hline
\end{tabular}

a. Predictors: (Constant), Total_X2, Total_X1

b. Dependent Variable: Total_Y

Berdasarkan Tabel 5 dapat dijelaskan bahwa model yang ditawarkan oleh peneliti memiliki tingkat kelayakan model yang tinggi dan setiap variablevariabel yang digunakan pada penelitian ini mampu untuk menjelaskan fenomena yang dianalisis. Dari tabel tersebut diperoleh F hitung sebesar 176,002, dan signifikansi sebesar 0,000. Nilai $\mathrm{F}$ hitung lebih besar dibandingkan $F$ tabel $(176,002>3,10)$ yang artinya Ho ditolak Ha diterima dan nilai signifikansi lebih kecil dari 0,05 $(0,000<$ $0,05)$, sehingga dinyatakan bahwa model sudah Layak.

Koefisien Determinasi adalah suatu alat yang digunakan untuk mengukur besarnya persentase pengaruh variabel bebas terhadap variabel terikat (Ghozali, 2011). Besarnya koefisien determinasi berkisar antara nol dan satu. Jika koefisien determinasi mendekati angka satu maka semakin besar pula pengaruh semua variabel bebas terhadap variabel terikat. Hasil koefisien determinasi sebagai berikut:
Tabel 6 Uji Koefisien Determinasi (R2)

Model Summary ${ }^{\mathrm{b}}$

\begin{tabular}{|l|c|r|r|r|r|}
\hline Model & $\mathrm{R}$ & $\begin{array}{c}\mathrm{R} \\
\text { Square }\end{array}$ & $\begin{array}{r}\text { Adjusted } \\
\text { R Square }\end{array}$ & $\begin{array}{r}\text { Std. Error of } \\
\text { the Estimate }\end{array}$ & $\begin{array}{r}\text { Durbin- } \\
\text { Watson }\end{array}$ \\
\hline 1 & $.895^{\mathrm{a}}$ & .802 & .797 & 2.282 & 2.163 \\
\hline
\end{tabular}

a. Predictors: (Constant), Total_X2,

Total_X1

b. Dependent Variable: Total_Y

Berdasarkan hasil perhitungan koefisien regresi dalam penelitian ini diperoleh nilai Adjusted R Square sebesar 0,797 . Hal ini berarti variabel independen dapat menjelaskan variasi dari variabel dependen sebesar 79,7\% sedangkan sisanya sebesar $19,3 \%$ dijelaskan oleh variabel lain di luar variabel penelitian.

\section{KESIMPULAN}

Berdasarkan hasil penelitian dan pembahasan maka dapat ditarik beberapa kesimpulan sebagai berikut :

1. Variabel kualitas produk (X1) berpengaruh signifikan terhadap keputusan pembelian (Y).

2. Variabel harga (X2) berpengaruh signifikan terhadap keputusan pembelian (Y).

\section{DAFTAR PUSTAKA}

Akrim Ashal Lubis. 2015. Pengaruh harga dan kualitas produk produk terhadap keputusan pembelian surat kabar pada PT. Suara barisan hijau harian orbit Medan. Jurnal Ilmiah Manajemen dan Bisnis Jurnal Ilmiah Manajemen dan Bisnis Vol. 16, No. 02,

Dharmmesta dan Handoko, Manajemen Pemasaran analisis Prilaku konsumen, (Yogyakarta: BPFE, 2011)

Dheany Arumsari. 2012. Analisis Pengaruh Kualitas Produk, Harga dan Promosi terhadap Keputusan Pembelian Air Minum Dalam Kemasan (AMDK) Merek Aqua (Studi pada Konsumen Toko Bhakti Mart KPRI Bhakti Praja 
Vol. 1 No. 1 Oktober 2021

\section{Provinsi Jawa}

$\begin{array}{lrr}\text { Provinsi Jawa } & \text { Tengah). } \\ \text { Universitas } & & \text { Dipenogoro } \\ \text { Semarang. } & \end{array}$

Endang Wijayanti. 2011. Pengaruh Harga dan Kualitas Produk terhadap Keputusan Pembelian Toyota Kijang (Studi Kasus Pada PT. NasmocoKaligawe Semarang)

Fandy Tjiptono. 2008. Strategik Pemasaran, Andi, Yogyakarta

Ferdinand, Augusty. 2006. Metode Penelitian Manajemen: Pedoman Penelitian untuk Skripsi, Tesis, dan Disertasi Ilmu Manajemen. Semarang: Universitas Diponegoro.

Ferdinand, Augusty. 2014. Metode Penelitian Manajemen: Pedoman Penelitian untuk Skripsi, Tesis, dan Disertasi Ilmu Manajemen. Semarang: Diponegoro.

Ferlina, A. \& Trenggana, M. 2018. Pengaruh Kualitas Produk dan Harga Terhadap Keputusan Pembelian Konsumen Laptop Asus. Jurnal Indonesia Membangun 17(2): 174-83.

Ferdinand, Augusty. 2006. Metode Penelitian. Semarang. Universitas Diponogoro

Firman. 2019. Pengaruh harga, store Atmosfer dan lokasi terhadap keputusan pembelian konsumen pada Eiger store komplek MMTC Medan. Fakultas ekonomi dan bisnis Islam Universitas Islam Negeri Sumatera Utara

Ghozali, I. 2008. Aplikasi Analisis Multivariate dalam Program.

Heriyanto, I. 2015. Analisis Pengaruh Produk, Harga, Distribusi dan Promosi Terhadap Keputusan Pembelian Serta Implikasinya Pada Kepuasan Pelanggan. Jurnal Ekonomi Bisnis \& Entrepreneurship 9(2):80-101.

Kodu, S. 2013. Harga, Kualitas Produk dan Kualitas Pelayanan Pengaruhnya Terhadap Keputusan Pembelian urgentrev.unram.ac.id

Mobil Toyota Avanza.Journal of Polymer Science, Part A: Polymer Chemistry 01(03):1251-59.

Kotler dan Keller et. Al, prinsif-prinsif Pemasaran (Jakarta:Erlangga, cet I 2008).

Kotler dan Keller, Manajemen Pemasaran (Jakarta:Erlangga, cet I 2008)

Kotler dan Keller. 2009. Manajemen Pemasaran. Jilid 1, Edisi 13. Jakarta: Erlangga

Kotler, Philip dan Gary Armstrong 2008. Prinsip-prinsip Pemasaran, edisi kedua belas,Erlangga, Jakarta

Kotler, Philip, and Keller, Kevin, Lane. 2006. Marketing Management, twelve edition. New Jersey : Prentice Hall.

Kotler, Philip, dan Keller, K. 2009. Manajemen Pemasaran Jilid 1, edisi Ketiga Belas, Terjemahan Bob Sabran, MM. Jakarta: Erlangga.

Kotler, Philip. 2002. Manajemen Pemasaran. Edisi Milenium. Jilid 2. Jakarta: PT. Indeks Kelompok Granmedia

Kotler, Philip. 2004. Manajemen Pemasaran: Analisis, Perencanaan, implementasi dan Kontrol, Edisi Sebelas. Alih Bahasa, Hendra Teguh. Jakarta: Penerbit PT. Prenhallindo.

Martini, T. 2015. Analisis Pengaruh Harga, Kualitas Produk dan Desain Terhadap Keputusan Pembelian Kendaraan Bermotor Merek Honda Jenis Skutermatic. Jurnal Penelitian 9(1):113-32.

Philip Kotler, Manajemen Pemasaran, Jilid I dan II. (Jakarta : PT. Indeks Kelompok Gramedia, 2005).

Rozalia. 2019. Pengaruh brand zmbassador terhadap citra merek dan keputusan pembelian sepatu nike dikota mataram. Fakultas Ekonomi dan Bisnis,Universitas Mataram.

Salman Farisi \& Qahfi Romula Siregar. 2020. Pengaruh Harga dan 


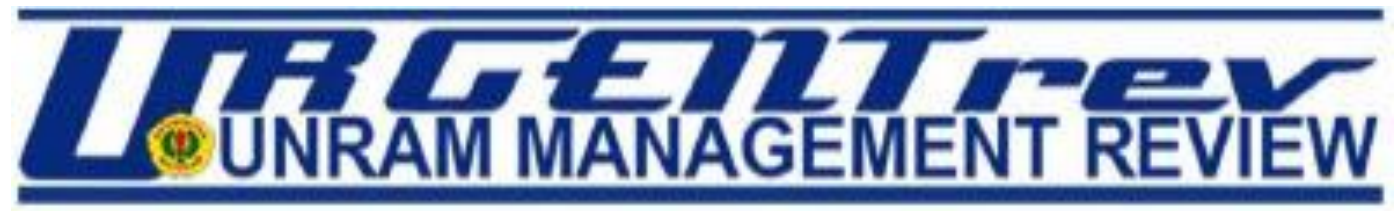

Vol. 1 No. 1 Oktober 2021

Promosi Terhadap Loyalitas

Pelanggan Pengguna Jasa

Transportasi Online di Kota

Medan. Jurnal Ilmiah Magister manajemen Vol, 3 No. 1 Program

Studi Manajemen, Universitas

Muhammadiyah Sumatera Utara

Medan, Indonesia Jl. Kapten

Muchtar Basri No. 3 Medan,

Sumatera Utara 20217

Setianingrum, A., Udaya, J., Efendi. 2015.

Prinsip-prinsip Pemasaran.

Yogyakarta: Andi Offiset

Siti Istiqomah. 2019. pengaruh kualitas produk dan harga terhadap keputusan pembelian makanan siap saji chicken holoc di plaza medan fair. Skripsi, fakultas ekonomi dan bisnis. Universitas muhammadiyah sumatera utara medan.

Triwahyuni, N. 2017. Pengaruh Kualitas Produk, Harga, Dan Promosi Terhadap Keputusan Pembelian Hp Oppo Pada Mahasiswa Fakultas Ekonomi Un Pgri Kediri.Jurnal Fakultas Ekonomi dan Bisnis Universitas Nusantara PGRI Kediri.

Weenas, J. R. S. 2013. Kualitas Produk, Harga, Promosi dan Kualitas Pelayanan Pengaruhnya Terhadap Keputusan Pembelian Spring Bed Comporta. Jurnal EMBA 1(4) 